\title{
Antibody Drug Conjugates
}

\begin{abstract}
Antibody drug conjugates (ADCs) are chemically engineered drugs consisting of monoclonal antibody $(\mathrm{mAb})$ and cytotoxic compound attached chemically by a linker. Upon attachment to a specific target antigen, ADC enters into the cell and payload is released, which finally leads to cell killing. Payloads are broadly divided into tubulin-disrupting agents and DNA-damaging agents. Most of the current ADCs utilize humanized mAbs, and fully human mAbs are under investigation. ADC development process is accelerated by better designing and bio-engineering methods.

Keywords: Antibody drug conjugate, linker, monoclonal antibody
\end{abstract}

\section{Introduction}

As per the Globocan 2018 data, approximately 1.1 million new cancer cases were diagnosed in India. ${ }^{[1]}$ Cancer figures in the top five causes of mortality in India and is the second most common cause of death in the West. ${ }^{[2]}$ For several decades, cancer therapy primarily consisted of surgery, radiation, and chemotherapy. With the availability of technological advancements in science, new classes of drugs such as antibody drug conjugates (ADCs), monoclonal antibodies, small-molecule kinase inhibitors, and immune checkpoint inhibitors have emerged. Conventional cytotoxic therapy carries certain unwanted toxicities by acting on normally proliferating cells such as bone marrow, mucosal lining, and hair follicle. To circumvent these off-target effects, a new class of drugs called ADCs were developed. ADCs ensure targeted drug delivery by a combination of monoclonal antibody $(\mathrm{mAb})$ and cytotoxic chemotherapy moiety (payload), which is joined by a chemical linker.

The German scientist Paul Ehrlich proposed the concept of "magic bullets" a century ago, describing them as those that identify the target without harming the organism. ${ }^{[3]}$ The legacy of discovery continued to evolve into various clinical applications including the ADC discovery. Though the ADC experiments date back to the 1980s, they have become more

\footnotetext{
This is an open access journal, and articles are distributed under the terms of the Creative Commons Attribution-NonCommercial-ShareAlike 4.0 License, which allows others to remix, tweak, and build upon the work non-commercially, as long as appropriate credit is given and the new creations are licensed under the identical terms.
}

For reprints contact: WKHLRPMedknow_reprints@wolterskluwer.com popular in recent times. ${ }^{[4]}$ Initial studies of ADC are related to methotrexate attached to an antibody by an ester conjugate to target specific cell lineage; it demonstrated good efficacy in vitro and in vivo. In the 1990s, the first ADC using chimeric and humanized monoclonal antibodies were tested. ${ }^{[5]}$

\section{Structural Components of Antibody Drug Conjugate}

The main components of ADC are antibody moiety, linker, and payload (chemotherapeutic agent). These three components have been discussed below.

\section{Antibody}

The antibody moiety is designed to target the specific tumor-associated antigen. Its primary function is to attach to a specific target and ultimately lead to internalization of the antigen-antibody complex, further leading to delivery of the payload intracellularly. There are more than 300 unique antigens described for therapeutic target. ${ }^{[6]}$ Some of the tumor-associated target antigens expressed in various cancers are listed in Table 1.

The target antigen expression should be low or absent on the normal tissues, thereby limiting off-target effects. The antibody commonly used is immunoglobulin $\mathrm{G}$ related. Depending on the type of antibody, ADCs can be classified into three generations: ${ }^{[7]}$

- $1^{\text {st }}$ generation - Chimeric antibody (e.g., brentuximab vedotin) How to cite this article: Bala S, Prasad SK. Antibody
drug conjugates. Indian J Med Paediatr Oncol
2020;41:889-92.

\section{Stalin Bala ${ }^{1}$, Siva K Prasad ${ }^{2}$}

${ }^{\prime}$ Department of Medical Oncology, Nizam's Institute of Medical Sciences, Hyderabad, Telangana, India, ${ }^{2}$ Department of Medical Oncology,

Santhiram Medical College and General Hospital, Nandyal, Andhra Pradesh, India

Submitted: 29-Jun-2020 Accepted in Revised Form: 19-Aug-2020

Published: 31-Dec-2020

Address for correspondence:

Dr. Siva K Prasad,

Santhiram Medical College and General Hospital,

Nandyal - 518501 Andhra Pradesh, India. E-mail: ksivaprasadkg@gmail. com

Access this article online

Website: www.ijmpo.org

DOI: 10.4103/ijmpo.ijmpo_313_20

Quick Response Code:

口伿口 ITp $+4+4 t$ sis

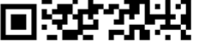




\begin{tabular}{ll}
\hline \multicolumn{1}{c}{ Table 1: List of various target antigens and cancers } \\
$\begin{array}{ll}\text { Tumor-associated } \\
\text { antigen }\end{array}$ & Cancer \\
\hline CD33 & Acute myeloid leukemia \\
CD30 & $\begin{array}{l}\text { Classical Hodgkin lymphoma, anaplastic large } \\
\text { cell lymphoma }\end{array}$ \\
CD22 & Acute lymphoblastic leukemia, non-Hodgkin \\
& lymphoma, chronic lymphocytic leukemia \\
Her-2 & Breast cancer \\
EGFR & Non-small cell lung cancer, glioblastoma \\
& multiforme \\
CD70 & Non-Hodgkin lymphoma, renal cell carcinoma \\
CD19 & B-cell leukemias \\
Mesothelin & Malignant pleural mesothelioma \\
PSMA & Prostate cancer \\
CD37 & B-cell leukemia, chronic lymphocytic \\
& leukemia, non-Hodgkin lymphoma \\
DLL-3 & Small cell lung cancer \\
CD138 & Multiple myeloma
\end{tabular}

- $2^{\text {nd }}$ generation - Humanized antibody (e.g., time-division multiplexing 1)

- $3^{\text {rd }}$ generation - Fully human antibody (e.g., enfortumab vedotin).

The ideal antibody should have high binding affinity, target antigen specificity, nil or low immunogenic, nil or low cross-reaction, and good systemic retention. ${ }^{[8]}$ Antibody is usually targeted at an antigen found only on target cells and that should not be downregulated on antibody binding. Recently, ADCs targeting the tumor microenvironment are undergoing clinical testing, which is beyond the conventional tumor-specific target strategy. ${ }^{[9]}$

\section{Linker}

The chemically engineered linker system forms the connection between the antibody and payload. The ideal properties of linkers are linker must be stable in the circulation so that ADC remains intact until it reaches target, conjugated inactively, nontoxic, and release the payload after the cellular internalization. ${ }^{[10]}$ Unstable linker might lead to premature release of payload into the circulation, leading to systemic toxicities and very stable linker loses its effectiveness.

The linkers are broadly classified into cleavable and noncleavable depending on the cleavage by various factors. ${ }^{[1]]}$ Examples of cleavable linkers are enzymatic (sensitive to lysosomal proteases), acid labile (sensitive to an acidic $\mathrm{pH}$ ), or disulfide (can be reduced by glutathione) and noncleavable linkers are thioether linker or hindered disulfide. ${ }^{[12]}$

\section{Cleavable Linkers}

Majority of the ADCs contain cleavable linkers. The main distinguishing feature is these are cleaved by various environmental factors such as $\mathrm{pH}$, redox potential, and enzymatic reaction, for example, hydrolysis of acid-labile bonds, enzymatic cleavage of ester, or amide bonds. These mechanisms may occur within the lysosome/endosome compartments or cytosol. Lysosomal protease-sensitive and glutathione-sensitive disulfide linkers are the most commonly used linkers in ADC development. Other types of linkers are acid-labile linker and $\beta$-glucuronide linker.

\section{Noncleavable Linker}

Noncleavable linkers resist proteolytic degradation and exhibit greater stability than cleavable linkers. After cellular internalization of the ADC, within the lysosome, these linkers are degraded and the antibody is released. One of the drawbacks of noncleavable linkers is reduced efficacy due to impaired membrane permeability.

\section{Payload/Warhead/Cytotoxic Moiety}

The final and effector component of ADC is payload, which gets released into the cell, after release into the cytoplasm. The ideal payload properties are able to cause cell death even at low dose, stable in the circulation and lysosome, soluble in the aqueous solution, low immunogenicity, small molecular weight, long half-life, and conjugation friendly. ${ }^{[12]}$ Payloads can be divided broadly into two groups: microtubule-disrupting agents and DNA-damaging agents. The list of payloads is given in Figure 1.

\section{Mechanism of Action of Antibody Drug Conjugate}

ADCs are given intravenously to prevent degradation of the $\mathrm{mAb}$ by gastric enzymes. The prerequisite for action of $\mathrm{ADC}$ is preferential expression of specific target on tumor tissue for selective entry into the cell. The mechanism is illustrated in Figure 2. Antibody-dependent cytotoxicity is a major mechanism of cell death in mAb-based therapy which is typically not observed in ADC action.

\section{Bystander Killing}

When the drug from ADC is released within the extracellular space or from target cell (following internalization and degradation of ADC), surrounding or bystander cells take up the drug and could be killed. This is known as bystander killing. The surrounding cells may or may not express the ADC target antigen. Bystander killing mediated by ADC depends on factors such as the extent of ADC internalization after binding to the target antigen, the type of linker (cleavable or noncleavable), and hydrophobicity of cytotoxic agent. ${ }^{[13]}$ ADCs containing cleavable linker may have more bystander killing compared to ADCs with noncleavable linker.

\section{Resistance Mechanisms against Antibody Drug Conjugate}

There are several proposed mechanisms by which resistance to ADC occurs. ${ }^{[14]}$ Although there is no single postulated 


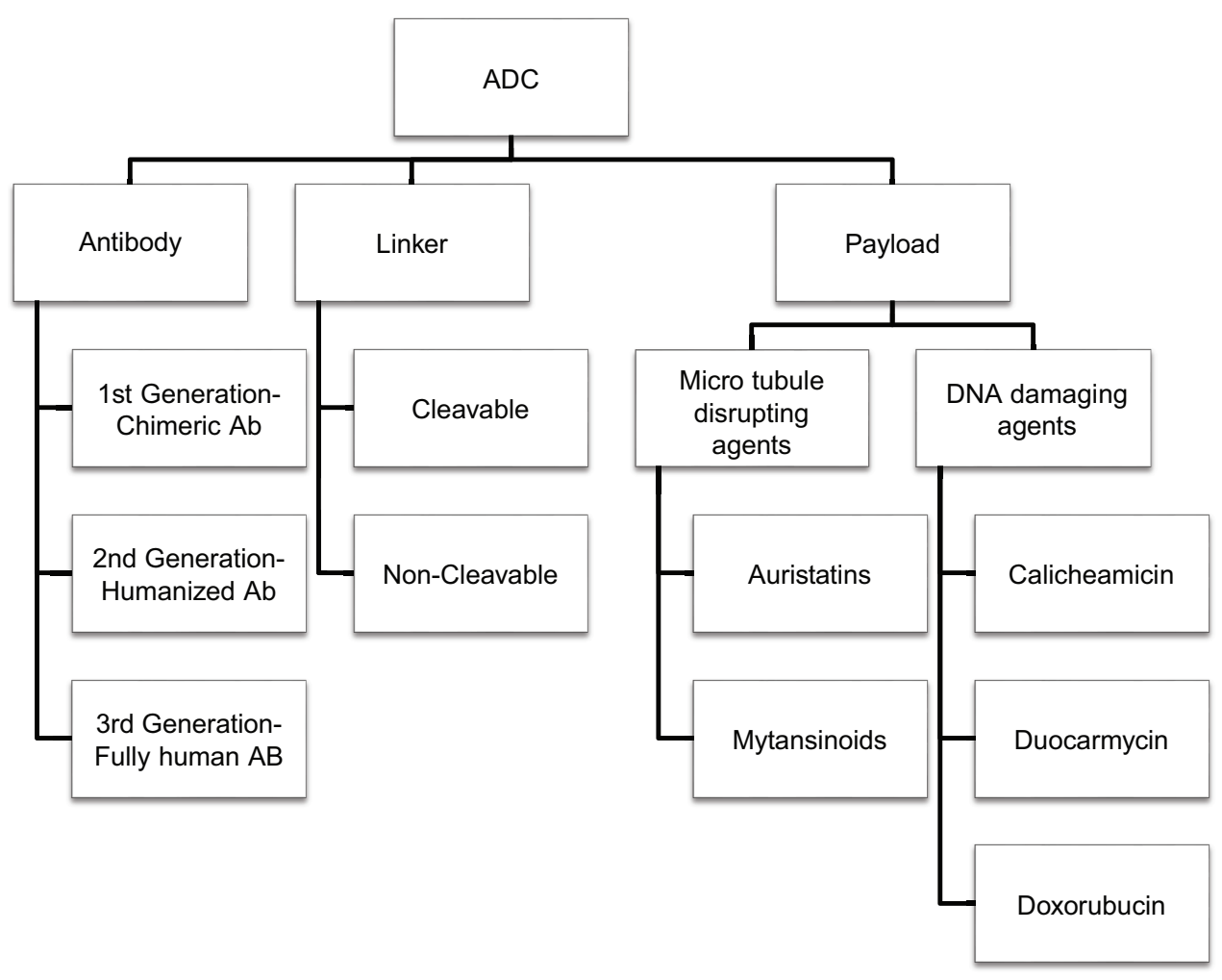

Figure 1: Comprehensive diagram of antibody drug conjugates

\begin{tabular}{|c|c|c|c|c|c|c|c|}
\hline Drug & Target Ag & Linker & Payload & Indication & $\begin{array}{c}\text { Year of } \\
\text { approval }\end{array}$ & Dose & Side effects \\
\hline $\begin{array}{l}\text { Gemtuzumab } \\
\text { ozogamicin }\end{array}$ & CD33 & $\begin{array}{l}\text { Hydrazone } \\
\text { cleavable }\end{array}$ & Calicheamicin & $\begin{array}{l}\text { CD33+ } \\
\text { AML }\end{array}$ & 2017 & $3 \mathrm{mg} / \mathrm{m}^{2} \mathrm{D} 1, \mathrm{D} 4, \mathrm{D} 7$ & $\begin{array}{l}\text { Neutropenia, thrombocytopenia, } \\
\text { infusion reactions, } \\
\text { venoocclusive disease }\end{array}$ \\
\hline $\begin{array}{l}\text { Iotuzumab } \\
\text { ozogamicin }\end{array}$ & $\mathrm{CD} 22$ & $\begin{array}{l}\text { Acid-labile } \\
\text { cleavable }\end{array}$ & Calichemicin & $\mathrm{R} / \mathrm{R}$ ALL & 2017 & $\begin{array}{c}0.8 \mathrm{mg} / \mathrm{m}^{2} \mathrm{D} 1 \text { then } 0.5 \\
\mathrm{mg} / \mathrm{m}^{2} \mathrm{D} 8, \mathrm{D} 15\end{array}$ & $\begin{array}{l}\text { Fever, thrombocytopenia, } \\
\text { neutropenia, LFT derangements }\end{array}$ \\
\hline $\begin{array}{l}\text { Brentuximab } \\
\text { vedotin }\end{array}$ & CD30 & $\begin{array}{l}\text { Protease } \\
\text { cleavable }\end{array}$ & MMAE & $\begin{array}{l}\text { cHL, } \\
\text { ALCL }\end{array}$ & 2018 & $\begin{array}{l}1.2 \mathrm{mg} / \mathrm{kg} \text { every } 2 \mathrm{as} \\
1^{\text {st-line therapy, } 1.8 \mathrm{mg} /} \\
\mathrm{kg} \text { every } 3 \text { weekly for } \\
\text { relapsed cHL and ALCL }\end{array}$ & $\begin{array}{l}\text { Nausea, neuropathy, } \\
\text { neutropenia, infection }\end{array}$ \\
\hline T-DM1 & Her2neu & $\begin{array}{l}\text { Thioether } \\
\text { noncleavable } \\
\text { linker }\end{array}$ & Mertansine & $\begin{array}{l}\text { Her2+ } \\
\text { breast } \\
\text { cancer }\end{array}$ & 2019 & $\begin{array}{l}3.6 \mathrm{mg} / \mathrm{kg} \text { every } \\
3 \text { weekly }\end{array}$ & $\begin{array}{l}\text { Thrombocytopenia, fatigue, LFT } \\
\text { derangements, anemia }\end{array}$ \\
\hline $\begin{array}{l}\text { Polatuzumab } \\
\text { vedotin }\end{array}$ & CD79b & $\begin{array}{l}\text { Protease } \\
\text { cleavable }\end{array}$ & MMAE & $\begin{array}{l}\mathrm{R} / \mathrm{R} \\
\mathrm{DLBCL}\end{array}$ & 2019 & $\begin{array}{c}1.8 \mathrm{mg} / \mathrm{kg} \text { every } \\
3 \text { weekly }\end{array}$ & $\begin{array}{l}\text { Neuropathy, neutropenia, } \\
\text { thrombocytopenia, progressive } \\
\text { multifocal leukoencephalopathy, } \\
\text { tumor lysis syndrome }\end{array}$ \\
\hline $\begin{array}{l}\text { Trastuzumab } \\
\text { deruxtecan }\end{array}$ & Her2neu & $\begin{array}{l}\text { Peptide } \\
\text { cleavable }\end{array}$ & $\begin{array}{l}\text { Dxd } \\
\text { (topoisomerase } \\
1 \text { inhibitor) }\end{array}$ & $\begin{array}{l}\text { Her2+ } \\
\text { breast } \\
\text { cancer }\end{array}$ & 2019 & $\begin{array}{l}5.4 \mathrm{mg} / \mathrm{kg} \text { every } \\
3 \text { weekly }\end{array}$ & $\begin{array}{l}\text { Interstitial lung disease, LV } \\
\text { dysfunction }\end{array}$ \\
\hline $\begin{array}{l}\text { Enfortumab } \\
\text { vedotin }\end{array}$ & Nectin-4 & $\begin{array}{l}\text { Protease } \\
\text { cleavable }\end{array}$ & MMAE & $\begin{array}{l}\text { Urothelial } \\
\text { carcinoma }\end{array}$ & 2019 & $\begin{array}{l}1.25 \mathrm{mg} / \mathrm{kg} \mathrm{D} 1, \mathrm{D} 8 \\
\mathrm{D} 15 \text { every } 4 \text { weekly }\end{array}$ & $\begin{array}{l}\text { Hyperglycemia, neuropathy, skin } \\
\text { reaction, extravasation reaction }\end{array}$ \\
\hline $\begin{array}{l}\text { Sacituzumab } \\
\text { govitecan }\end{array}$ & Trop-2 & $\begin{array}{l}\text { Hydrolysable } \\
\text { cleavable }\end{array}$ & $\begin{array}{l}\mathrm{SN}-38 \\
\text { (topoisomerase } \\
1 \text { inhibitor) }\end{array}$ & $\begin{array}{l}\text { Metastatic } \\
\text { TNBC }\end{array}$ & 2020 & $\begin{array}{l}10 \mathrm{mg} / \mathrm{kg} \mathrm{D} 1, \mathrm{D} 8 \text { every } \\
3 \text { weekly }\end{array}$ & $\begin{array}{l}\text { Nausea, neutropenia, anemia, } \\
\text { vomiting, diarrhea, fatigue }\end{array}$ \\
\hline
\end{tabular}

MMAE: Monomethyl auristatin E, ALCL: Anaplastic large cell lymphoma, AML: Acute myeloid leukemia, ALL: Acute lymphoblastic leukemia, DLBCL: Diffuse large B-cell lymphoma, TNBC: Triple-negative breast cancer, LFT: Liver function test, LV: Left ventricular

way, most often, there will be multiple pathways. These mechanisms include:
1. Alterations of target antigen

2. Interference with $\mathrm{ADC}$ internalization 


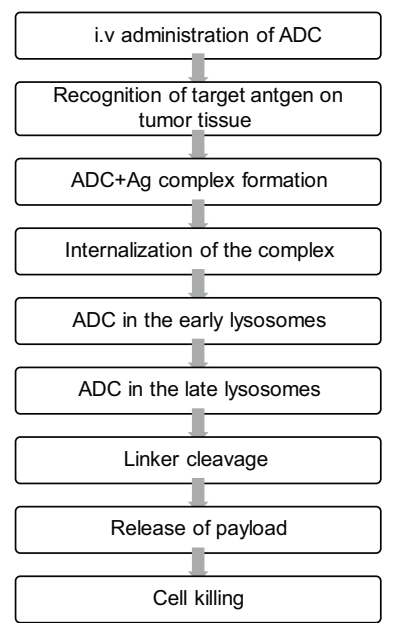

Figure 2: Mechanism of action of antibody drug conjugate

3. Changes in trafficking pathway(s)

4. Modification of cell cycle and its regulators

5. Activation of drug efflux pump

6. Apoptotic dysregulation.

The list of approved ADCs and their indications is given in Table 2.

\section{Immunoconjugates and Radioimmunoconjugates}

These are similar group of therapeutic agents where the cytotoxic agent is a toxin and radioisotope. An example of immunoconjugate is moxetumomab pasudotox, an anti-CD22 immunotoxin, in which an anti-CD22 antibody is fused to a toxin PE38 (pseudomonas exotoxin A). It was approved for the treatment of relapsed and refractory hairy cell leukemia. ${ }^{90} \mathrm{Y}$-Ibritumomab tiuxetan is a radioimmunoconjugate which is used in the treatment of non-Hodgkin lymphoma and the targeted antigen is CD20.

\section{Acknowledgment}

We sincerely acknowledge Dr. D Raghunadhrao for preparation of this manuscript.

\section{Financial support and sponsorship}

Nil.

\section{Conflicts of interest}

There are no conflicts of interest.

\section{References}

1. 356-india-fact-sheets.pdf. Available from: https://gco.iarc.fr/ today/data/factsheets/populations/356-india-fact-sheets.pdf. [Last accessed on 2020 Jun 03].

2. Census of India Website : Causes of Death Statistics. Available from: https://censusindia.gov.in/vital_statistics/causesofdeath.html. [Last accessed on 2020 May 23].

3. Strebhardt K, Ullrich A. Paul Ehrlich's magic bullet concept: 100 years of progress. Nat Rev Cancer 2008;8:473-80.

4. Kanellos J, Pietersz GA, McKenzie IF. Studies of methotrexatemonoclonal antibody conjugates for immunotherapy. JNCI J Natl Cancer Inst 1985;75:319-32.

5. Trail PA, Willner D, Lasch SJ, Henderson AJ, Hofstead S, Casazza AM, et al. Cure of xenografted human carcinomas by BR96-doxorubicin immunoconjugates. Science 1993;261:212-5.

6. Strohl WR. Current progress in innovative engineered antibodies. Protein Cell 2018;9:86-120.

7. Khongorzul P, Ling CJ, Khan FU, Ihsan AU, Zhang J. Antibody-drug conjugates: A comprehensive review. Mol Cancer Res 2020;18:3-19.

8. Hughes B. Antibody-drug conjugates for cancer: Poised to deliver? Nat Rev Drug Discov 2010;9:665-7.

9. Casi G, Neri D. Noninternalizing targeted cytotoxics for cancer therapy. Mol Pharm 2015;12:1880-4.

10. Alley SC, Benjamin DR, Jeffrey SC, Okeley NM, Meyer DL, Sanderson RJ, et al. Contribution of linker stability to the activities of anticancer immunoconjugates. Bioconjug Chem 2008;19:759-65.

11. Tsuchikama K, An Z. Antibody-drug conjugates: recent advances in conjugation and linker chemistries. Protein Cell 2018;9:33-46.

12. Nasiri H, Valedkarimi Z, Aghebati-Maleki L, Majidi J. Antibodydrug conjugates: Promising and efficient tools for targeted cancer therapy. J Cell Physiol 2018;233:6441-57.

13. Staudacher AH, Brown MP. Antibody drug conjugates and bystander killing: Is antigen-dependent internalisation required? Br J Cancer 2017;117:1736-42.

14. García-Alonso S, Ocaña A, Pandiella A. Resistance to antibodydrug conjugates. Cancer Res 2018;78:2159-65. 